JURNAL GIZI DAN DIETETIK INDONESIA

Vol. 4, No. 3, September 2016: 139-146
Tersedia online pada: http://ejournal.almaata.ac.id/index.php/IJND DOI : http://dx.doi.org/10.21927/ijnd.2016.4(3).139-146

\title{
Asupan lemak dan aktivitas fisik serta hubungannya dengan kejadian hipertensi pada pasien rawat jalan
}

\author{
The correlation between fat intake and physical activity, their correlation with hypertension among \\ outpatients
}

Lusi Ayu Kartika1 ${ }^{1}$ Effatul Afifah¹, Isti Suryani²

\begin{abstract}
Background: Hypertension is a great health problem in Indonesia. The causes of hypertension are high fat intake and low physical activity. In Indonesia, the prevalence of hipertension in 2013 was $28.5 \%$, while in Yogyakarta was $25.7 \%$.

Objectives: To know the correlation between fat intake and physical activity and hypertension among outpatients in Panembahan Senopati Bantul Hospital, Yogyakarta.

Methods: This was an observasional study with case-control design. Cases were outpatients aged 30-60 years with hypertension. Controls were outpatients aged 30-60 years without hypertension. Data were analyzed by using univariable (descriptive), bivariable (chi-square test), and multivariable anaysis (logistic regression).

Results: Bivariate analysis showed that there were significant correlation between fat intake $(p=0,009$, OR:3,839, 95\% Cl: 1,357-10,861), age ( $p=0,008$, OR:3,37, 95\% Cl:1,340-8,476) and hypertension. However, no significant correlation between physical activity $(\tau=0,075, p=0,451)$, body mass index ( $p=0,065$, OR:2,155, 95\% Cl:0,949-4,893) and hypertension. Multivariate analysis showed that the most influential variable against hypertension was fat intake ( $p=0,010$, OR (95\% Cl):4,246 (1,418-12,721)).

Conclusions: There ware significant correlation between fat intake, age, and hypertension, while physical activity and body mass index failed to prove the correlation with hypertension.
\end{abstract}

KEYWORDS: hypertension, fat intake, physical activity, BMI, aged

\begin{abstract}
ABSTRAK
Latar belakang: Hipertensi masih menjadi permasalahan kesehatan yang besar di Indonesia. Penyebab terjadinya hipertensi di antaranya adalah asupan makanan tinggi lemak dan aktivitas fisik yang rendah. Di Indonesia, tahun 2013 prevalensi stunting sebanyak 28,5\%, dan di Daerah Istimewa Yogyakarta sebanyak $25,7 \%$.

Tujuan: Untuk mengetahui hubungan antara asupan lemak dan aktivitas fisik dengan kejadian hipertensi pada pasien rawat jalan di RSUD Panembahan Senopati Bantul Yogyakarta.

Metode: Jenis penelitian observasional dengan rancangan kasus kontrol. Kasus adalah pasien rawat jalan usia 30 - 60 tahun dengan diagnosa hipertensi. Kontrol adalah pasien rawat jalan usia 30 - 60 tahun yang tidak hipertensi. Analisis data menggunakan analisis univariat (deskriptif), bivariat (uji chi-square), dan multivariat (uji regresi logistik).

Hasil: Analisis bivariat menunjukkan bahwa asupan lemak ( $p=0,009,0 R: 3,839,95 \%$ Cl:1,357-10,861), dan usia ( $p=0,008$, OR=3,37, 95\% Cl:1,340-8,476) memiliki hubungan yang signifikan dengan kejadian hipertensi. Aktivitas fisik ( $T=0,075, p=0,451)$, dan IMT ( $p=0,065$, OR:2,155, 95\% Cl:0,949-4,893) tidak memiliki hubungan yang signifikan dengan kejadian hipertensi. Analisis multivariat menunjukkan variabel
\end{abstract}

\footnotetext{
${ }^{1}$ Program Studi S1 IImu Gizi, akultas IImu-ilmu kesehatan, Universitas Alma Ata, Jl. Ring Road Barat Daya No 1, Yogyakart,. e-mail: luzykartika@gmail.com

${ }^{2}$ Jurusan Gizi Poltekkes Kemenkes Yogyakarta, Jl. Tata Bumi No 3, Banyuraden, Gamping, Sleman
} 
yang paling berpengaruh terhadap terjadinya hipertensi adalah asupan lemak ( $p=0,010, \mathrm{OR}(95 \% \mathrm{Cl}): 4,246$ $(1,418-12,721))$.

Kesimpulan: Ada hubungan yang signifikan antara asupan lemak dan usia dengan kejadian hipertensi, namun aktivitas fisik dan IMT tidak berhasil membuktikan hubungan dengan kejadian hipertensi.

KATA KUNCI : hipertensi, asupan lemak, aktivitas fisik, IMT, usia

\section{PENDAHULUAN}

Hingga saat ini hipertensi masih merupakan permasalahan kesehatan yang besar di Indonesia. Hipertensi adalah keadaan tekanan darah di pembuluh darah meningkat dalam jangka waktu tertentu. Hal tersebut terjadi karena jantung bekerja lebih keras memompa darah untuk memenuhi kebutuhan oksigen dan nutrisi tubuh. Dalam jangka waktu yang panjang, penyakit hipertensi dapat mengganggu fungsi organorgan lain, terutama organ-organ vital seperti jantung dan ginjal (1).

Prevalensi hipertensi di dunia sampai pada tahun 2008 mencapai 40\% (2), sedangkan di Indonesia prevalensi hipertensi sampai tahun 2013 pada usia $\geq 18$ tahun mencapai 28,5\% (2). Di Daerah Istimewa Yogyakarta (DIY), prevalensi hipertensi tahun 2013 mencapai 25,7\% (1). Berdasar hasil studi pendahuluan di RSUD Panembahan Senopati, jumlah kasus hipertensi primer usia 20-60 tahun pada bulan Maret-Mei 2015 mencapai 1.099 pasien (3).

Banyak faktor yang mempengaruhi meningkatnya penderita hipertensi. Faktor-faktor tersebut antara lain: konsumsi makanan tinggi natrium dan lemak tanpa diimbangi konsumsi buah dan sayur, konsumsi alkohol, aktivitas fisik yang sangat rendah, faktor stres, sosio-ekonomi, dan genetik (2).

Konsumsi lemak yang tinggi berpengaruh pada tingginya simpanan kolesterol di dalam darah. Simpanan ini nantinya akan menumpuk pada pembuluh darah menjadi plaque yang akan menyebabkan penyumbatan pada pembuluh darah. Penyumbatan ini menjadikan elastisitas pembuluh darah berkurang sehingga volume dan tekanan darah meningkat. Hal inilah yang memicu terjadinya hipertensi (4). Di Indonesia, proporsi penduduk dengan perilaku konsumsi makanan berlemak, berkolesterol, dan makanan gorengan $\geq 1$ kali per hari mencapai $40,7 \%$ di tahun 2013 , sedangkan di
Provinsi Daerah Istimewa Yogyakarta menduduki peringkat kedua tertinggi di Indonesia setelah Provinsi Jawa Tengah dengan angka $50,7 \%$ di tahun 2013(1).

Perilaku aktivitas fisik rendah berpengaruh pada menurunnya elastisitas pembuluh darah dan sistem jantung. Hal inilah yang menjadikan tekanan darah meningkat (1). Perilaku aktivitas fisik kurang aktif pada umur $\geq 10$ tahun di Indonesia hingga tahun 2013 mencapai 26,1\%, sedangkan di Provinsi Daerah Istimewa Yogyakarta mencapai 20,8\% (1).

Tujuan penelitian ini adalah ingin mengetahui hubungan antara tingkat asupan lemak dan aktivitas fisik dengan kejadian hipertensi pada pasien rawat jalan RSUD Panembahan Senopati Bantul Yogyakarta.

\section{BAHAN DAN METODE}

Penelitian ini merupakan penelitian observasional analitik yang menggunakan rancangan kasus, kontrol. Sampel penelitian ini adalah pasien rawat jalan di RSUD Panembahan Senopati Bantul Yogyakarta. Teknik pengumpulan sampel menggunakan cara non random sampling (by accidental sampling). Besar sampel dalam penelitian ini adalah 96 responden dengan jumlah kelompok kasus 48 responden dan kelompok kontrol sebanyak 48 responden. Instrumen yang digunakan yaitu kuesioner terstruktur dengan teknik wawancara. Identitas pasien diambil dengan menggunakan kuesioner terstruktur yang terdiri dari nama, umur, jenis kelamin, tingkat pendidikan, pekerjaan, dan alamat. Data tekanan darah diambil dengan menggunakan data sekunder, data asupan makan diambil dengan menggunakan kuesioner food frequency-questionnaire (FFQ) satu bulan terakhir, data aktivitas fisik diambil dengan menggunakan kuesioner international physical activity questionary (IPAQ), data antropometri 
diambil dengan timbangan injak digital dan mikrotoa. Analisis bivariat menggunakan uji chisquare, dan analisis multivariat menggunakan regresi logistik.

HASIL

\section{Karakteristik responden}

Jumlah responden dalam penelitian ini adalah 96 responden yang terdiri dari 48 kelompok kasus dan 48 kelompok kontrol. Karakteristik responden penelitian meliputi jenis kelamin, usia, pendidikan, dan pekerjaaan. Berdasarkan Tabel 1, sebagian besar responden yang mengalami hipertensi, berjenis kelamin perempuan $(75 \%)$, berusia $>45$ tahun $(81,25 \%)$, pendidikan SMA $(31,25 \%)$, bekerja sebagai ibu rumah tangga (60\%). Pada responden yang tidak mengalami hipertensi, sebagian besar berjenis kelamin perempuan $(77,08 \%)$, pendidikan SMA $(39,58 \%)$, dan bekerja sebagai ibu rumah tangga $(50 \%)$.

\section{Hubungan asupan lemak dengan kejadian hipertensi}

Analisis bivariat pada Tabel 2, menunjukkan bahwa sebagian besar pasien hipertensi cenderung mengkonsumsi lemak tinggi $(87,50 \%)$. Hasil analisis statistik chi-square menunjukkan hasil signifikan yaitu $p=0,009$. Dari hasil tersebut dapat

Tabel 1. Karakteristik responden pada kelompok hipertensi dan tidak hipertensi

\begin{tabular}{|c|c|c|c|c|c|c|}
\hline \multirow[t]{2}{*}{ Karakteristik } & \multicolumn{2}{|c|}{$\begin{array}{l}\text { Hipertensi } \\
\text { (Kasus) }\end{array}$} & \multicolumn{2}{|c|}{$\begin{array}{l}\text { Tidak hipertensi } \\
\text { (Kontrol) }\end{array}$} & \multicolumn{2}{|c|}{ Jumlah } \\
\hline & $\mathbf{n}$ & $\%$ & $\mathbf{n}$ & $\%$ & $\mathbf{n}$ & $\%$ \\
\hline \multicolumn{7}{|l|}{ Jenis kelamin } \\
\hline Laki-laki & 12 & 25 & 11 & 22,92 & 23 & 23,96 \\
\hline Perempuan & 36 & 75 & 37 & 77,08 & 73 & 76,04 \\
\hline Total & 48 & 100 & 48 & 100 & 96 & 100 \\
\hline \multicolumn{7}{|l|}{ Usia } \\
\hline$\geq 45$ tahun & 39 & 81,25 & 27 & 56,25 & 66 & 68,75 \\
\hline$<45$ tahun & 9 & 18,75 & 21 & 43,75 & 30 & 31,25 \\
\hline Total & 48 & 100 & 48 & 100 & 96 & 100 \\
\hline \multicolumn{7}{|l|}{ Pendidikan } \\
\hline Tidak pernah sekolah & 1 & 2,08 & 2 & 4,17 & 3 & 3,13 \\
\hline Tamat SD & 12 & 25 & 8 & 16,67 & 20 & 20,83 \\
\hline Tamat SMP & 9 & 18,75 & 11 & 22,92 & 20 & 20,83 \\
\hline Tamat SMA & 15 & 31,25 & 19 & 39,58 & 34 & 35,42 \\
\hline Tamat akademi / perguruan tinggi & 11 & 22,92 & 8 & 16,67 & 19 & 19,79 \\
\hline Total & 48 & 100 & 48 & 100 & 96 & 100 \\
\hline \multicolumn{7}{|l|}{ Pekerjaan } \\
\hline Buruh, pedagang/ wiraswasta, petani & 12 & 25 & 20 & 41,67 & 32 & 33 \\
\hline $\begin{array}{l}\text { Pegawai perusahaan swasta, PNS, } \\
\text { TNI, pensiunan }\end{array}$ & 7 & 15 & 1 & 2,08 & 11 & 11 \\
\hline Ibu rumah tangga dan lainnya & 29 & 60 & 24 & 50 & 53 & 55 \\
\hline Total & 48 & 100 & 45 & 93,75 & 96 & 100 \\
\hline
\end{tabular}

Tabel 2. Analisis bivariat hubungan asupan lemak responden dengan kejadian hipertensi

\begin{tabular}{|c|c|c|c|c|c|c|c|}
\hline \multirow{2}{*}{$\begin{array}{c}\text { Asupan } \\
\text { lemak }\end{array}$} & \multicolumn{2}{|c|}{$\begin{array}{c}\text { Kasus } \\
\text { (Hipertensi) }\end{array}$} & \multicolumn{2}{|c|}{$\begin{array}{c}\text { Kontrol } \\
\text { (Tidak hipertensi ) }\end{array}$} & \multirow[t]{2}{*}{$\mathbf{p}$} & \multirow[t]{2}{*}{ OR } & \multirow[t]{2}{*}{ (95\% Cl) } \\
\hline & $\mathbf{n}$ & $\%$ & $\mathbf{n}$ & $\%$ & & & \\
\hline Lebih & 42 & 87,50 & 31 & 64,58 & \multirow{3}{*}{$0,009^{*}$} & \multirow{3}{*}{3,839} & \multirow{3}{*}{$1,357-10,861$} \\
\hline Cukup & 6 & 12,50 & 17 & 35,42 & & & \\
\hline Total & 48 & 100 & 48 & 100 & & & \\
\hline
\end{tabular}

*Signifikan $p<0,05$ 
diketahui bahwa terdapat hubungan yang signifikan antara asupan lemak dengan kejadian hipertensi. Responden dengan asupan lemak lebih berisiko 3,8 kali lebih besar untuk mengalami hipertensi dibandingkan dengan responden dengan asupan lemak yang sedang dan rendah (OR: 3,839, 95\% Cl:1,357 - 10,861).

\section{Hubungan aktivitas fisik dengan kejadian hipertensi}

Analisis bivariat pada Tabel 3, menunjukkan bahwa sebagian besar pasien hipertensi memiliki aktivitas fisik yang rendah (68,75\%). Hasil analisis statistik Kendal tau menunjukkan nilai Kendal tau sebesar 0,075 dengan tingkat signifikansi Sig (2-tailed) 0,451. Dengan demikian dapat dikatakan tidak terdapat hubungan signifikan antara aktivitas fisik dengan kejadian hipertensi.
Hubungan indeks massa tubuh (IMT) dengan kejadian hipertensi

Analisis bivariat pada Tabel 4 menunjukkan sebagian besar pasien hipertensi memiliki IMT>22 $(54,17 \%)$. Hasil analisis chi-square menunjukkan $p=0,065$ yang berarti tidak terdapat hubungan yang signifikan IMT dengan kejadian hipertensi.

\section{Hubungan usia dengan kejadian hipertensi}

Sebagian besar pasien hipertensi berusia $>45$ tahun $(81,25 \%)$. Hasil analisis chi-square menunjukkan terdapat hubungan yang signifikan antara usia dengan kejadian hipertensi $(p=0,008)$ dan responden dengan usia $\geq 45$ tahun berisiko 3,37 kali lebih untuk mengalami hipertensi dibandingkan dengan responden dengan usia $<45$ tahun (OR:3,37, 95\% Cl:1,340-8,476) (Tabel 5).

Tabel 3. Analisis bivariat hubungan aktivitas fisik responden dengan kejadian hipertensi

\begin{tabular}{lcccccc}
\hline \multirow{2}{*}{ Aktivitas fisik } & Kasus (Hipertensi) & \multicolumn{2}{c}{$\begin{array}{c}\text { Kontrol } \\
\text { (Tidak hipertensi ) }\end{array}$} & $\boldsymbol{T}$ & p \\
\cline { 2 - 5 } & $\mathbf{n}$ & $\%$ & $\mathbf{n}$ & $\mathbf{\%}$ & & \\
\hline Rendah & 33 & 68,75 & 31 & 64,58 & & \\
Sedang & 14 & 29,17 & 11 & 22,92 & 0,075 & 0,451 \\
Tinggi & 1 & 2,08 & 6 & 12,50 & & \\
Total & 48 & 100 & 48 & 100 & & \\
\hline
\end{tabular}

Tabel 4. Analisis bivariat hubungan indeks massa tubuh (IMT) responden dengan kejadian hipertensi

\begin{tabular}{|c|c|c|c|c|c|c|c|}
\hline \multirow[t]{2}{*}{ IMT } & \multicolumn{2}{|c|}{$\begin{array}{c}\text { Kasus } \\
\text { (Hipertensi) }\end{array}$} & \multicolumn{2}{|c|}{$\begin{array}{c}\text { Kontrol } \\
\text { (Tidak hipertensi) }\end{array}$} & \multirow[t]{2}{*}{$\mathbf{p}$} & \multirow[t]{2}{*}{ OR } & \multirow[t]{2}{*}{$(95 \%$ Cl) } \\
\hline & $n$ & $\%$ & $n$ & $\%$ & & & \\
\hline$>22,9 \mathrm{~kg} / \mathrm{m}^{2}$ & 26 & 54,17 & 17 & 35,42 & \multirow{3}{*}{0,065} & \multirow{3}{*}{2,155} & \multirow{3}{*}{$0,949-4,893$} \\
\hline$\leq 22,9 \mathrm{~kg} / \mathrm{m}^{2}$ & 22 & 45,83 & 31 & 64,58 & & & \\
\hline Total & 48 & 100 & 48 & 100 & & & \\
\hline
\end{tabular}

Tabel 5. Analis bivariat hubungan usia dengan kejadian hipertensi

\begin{tabular}{|c|c|c|c|c|c|c|c|}
\hline \multirow[t]{2}{*}{ Usia } & \multicolumn{2}{|c|}{$\begin{array}{c}\text { Kasus } \\
\text { (Hipertensi ) }\end{array}$} & \multicolumn{2}{|c|}{$\begin{array}{c}\text { Kontrol (Tidak } \\
\text { hipertensi ) }\end{array}$} & \multirow[t]{2}{*}{$\mathbf{p}$} & \multirow[t]{2}{*}{ OR } & \multirow[t]{2}{*}{ (95\% Cl) } \\
\hline & $\mathbf{n}$ & $\%$ & $\mathbf{n}$ & $\%$ & & & \\
\hline$\geq 45$ tahun & 39 & 81,25 & 27 & 56,25 & \multirow{3}{*}{$0,008^{*}$} & \multirow{3}{*}{3,37} & \multirow{3}{*}{$1,340-8,476$} \\
\hline$<45$ tahun & 9 & 18,75 & 21 & 43,75 & & & \\
\hline Total & 48 & 100 & 48 & 100 & & & \\
\hline
\end{tabular}

*Siginifikan $p<0,05$ 
Tabel 6. Hasil analisis multivariat regresi logistik

\begin{tabular}{lccccc}
\hline \multirow{2}{*}{ Variabel } & \multirow{2}{*}{ Koefisien } & \multirow{2}{*}{$\mathbf{p}$} & \multirow{2}{*}{ OR } & \multicolumn{2}{c}{$\mathbf{9 5 \%} \mathbf{~ C l}$} \\
\cline { 5 - 6 } & & & & Min & Maks \\
\hline Asupan lemak & 1,446 & 0,010 & 4,246 & 1,418 & 12,721 \\
IMT & 0,787 & 0,083 & 2,197 & 0,901 & 4,355 \\
Usia & 1,347 & 0,007 & 3,846 & 1,444 & 10,246 \\
Konstanta & $-2,405$ & 0,000 & 0,090 & & \\
\hline
\end{tabular}

\section{Analisis multivariat}

Asupan lemak menunjukkan hubungan yang bermakna dengan kejadian hipertensi dengan nilai $p=0,010$ dan nilai OR $(95 \%$ Cl):4,246 $(1,418$ - 12,721) (Tabel 6). Artinya, responden dengan asupan lemak tinggi memiliki risiko 4,246 kali lebih besar untuk mengalami hipertensi dibandingkan responden dengan asupan lemak normal. Apabila dibandingkan analisis pada hasil hubungan asupan lemak dengan kejadian hipertensi pada bivariat (OR:3,3) dan multivariat (OR:4,246), maka nilai perbandingannya sebesar $10,5 \%$ (OR $\geq 10 \%$ ), sehingga IMT dan aktivitas fisik disebut variabel confounding.

\section{BAHASAN}

\section{Karakteristik responden}

Kejadian hipertensi akan meningkat seiring dengan bertambahnya usia. Pada penelitian ini, responden dengan usia $\geq 45$ (81,25\%) mengalami hipertensi. Hipertensi banyak terjadi pada wanita karena wanita mengalami masa menopause yang dibuktikan dalam penelitian ini (Tabel 1). Wanita menopause berisiko dua kali lebih besar mengalami hipertensi karena menurunnya hormon esterogen yang dapat berfungsi sebagai vasodilator (5).

\section{Hubungan asupan lemak dengan kejadian hipertensi}

Berdasarkan uji chi-square, diketahui bahwa terdapat hubungan yang signifikan antara asupan lemak dengan kejadian hipertensi. Responden dengan asupan lemak tinggi berisiko 3,8 kali lebih besar untuk mengalami hipertensi dibanding responden dengan asupan lemak sedang dan rendah (OR:3,839, 95\% Cl:1,357-10,861) (Tabel 2).
Mengonsumsi makanan tinggi lemak jenuh, lemak terhidrogenasi, dan tinggi kolesterol namun rendah polyunsaturated fatty acid (PUFA) dalam jumlah yang berlebih dapat berpengaruh terhadap kadar kolesterol dalam darah (6). Konsumsi lemak yang berlebih dapat meningkatkan kadar kolesterol dalam darah terutama kadar kolesterol low density lipoprotein (LDL). Kolesterol akan menempel pada dinding pembuluh darah sehingga akan terbentuk plaque. Plaque akan menyumbat pembuluh darah dan tersebut dapat berpengaruh terhadap kelenturan pembuluh darah $(4,7)$.

Dari hasil wawancara FFQ diketahui bahwa responden dengan asupan lemak berlebih sering mengkonsumsi makanan sumber lemak jenuh seperti daging, jerohan, mentega, dan beberapa sumber lemak nabati seperti minyak kelapa sawit dan santan. Responden juga sering mengonsumsi sumber lemak jenuh dalam bentuk gorengan seperti bakwan, pisang goreng, tempe goreng, lumpia, kerupuk, keripik, dan lain-lain. Selain itu, responden mengolah sebagian besar lauk harian mereka dengan cara digoreng, ditumis, maupun dimasak menggunakan santan. Selain itu, sebagian besar responden juga menjelaskan sering mengolah daging sapi menjadi rendang dan lauk-lauk khas warung masakan padang. Lemak jenuh dalam makanan-makanan tersebut dapat meningkatkan kadar kolesterol darah.

Penelitian ini sejalan dengan penelitian di Semarang tahun 2007 pada pasien Rumah Sakit Umum Semarang yang menunjukkan adanya hubungan yang signifikan antara asupan lemak total dengan tekanan darah sistolik $(p=0,024)$ dan diastolik ( $p=0,02, r=0,34)$ pada penderita hipertensi (8). Hal ini juga sejalan dengan penelitian lain di Semarang tahun 2012 pada siswa di 3 SMP di Semarang yang menunjukkan bahwa asupan 
lemak berhubungan signifikan dengan kejadian hipertensi dengan nilai $p=0,002$. Selain itu, asupan lemak tinggi memiliki 4,3 kali berisiko lebih besar untuk hipertensi dibanding asupan lemak normal (OR:4,3, 95\% Cl:1,696-11,069) (9). Hasil penelitian ini juga sesuai dengan penelitian pada tahun 2015 di Minahasa yang menunjukkan adanya hubungan yang signifikan antara asupan lemak dengan kejadian hipertensi $(p=0,000)(10)$. Konsumsi lemak yang berlebih akan meningkatkan kadar kolesterol dalam darah terutama kolesterol LDL yang akan membentuk plaque(6).

\section{Hubungan aktivitas fisik dengan kejadian hipertensi}

Berdasarkan hasil analisis statistik Kendal tau diketahui bahwa tidak ada hubungan signifikan antara aktivitas fisik dengan kejadian hipertensi. Hal ini ditunjukkan dengan nilai Kendal tau sebesar 0,75 dengan tingkat signifikansi Sig (2-tailed) 0,451 (Tabel 3).

Aktivitas yang rendah akan menurunkan elastisitas sistem jantung dan pembuluh darah (2). Sebaliknya, aktivitas yang tinggi akan meningkatkan elastisitas sistem jantung dan pembuluh darah (2). Setelah beraktivitas fisik, tekanan darah arteri akan meningkat (2). Hal ini dipengaruhi oleh penurunan curah jantung dan resistentensi perifer total (11). Dari Hasil wawancara IPAQ diketahui kecenderungan responden melakukan aktivitas fisik yang rendah.

Penelitian ini sejalan dengan penelitian di Semarang tahun 2014 dengan jumlah populasi 68 responden (kasus $=34$ responden, kontrol=34 responden) dan metode observasional dengan desain case control yang menunjukkan tidak ada hubungan yang signifikan antara tingkat aktivitas fisik dengan kejadian hipertensi pada wanita menopause di Kelurahan Bojongsalam $(p=0,77)$ (5). Hasil penelitian ini juga sesuai sebuah metaanalisis yang menunjukkan tidak ada hubungan antara aktivitas fisik dengan kejadian hipertensi (12). Sebaliknya, penelitian di Yogyakarta menunjukkan terdapat hubungan yang signifikan antara aktivitas fisik dan hipertensi pada lansia di Kecamatan Kasihan Bantul $(p=0,004)$ (13). Obesitas merupakan faktor risiko peningkatan mortalitas, hipertensi, diabetes, hiperlipidemia, hiperglikemia, dan penyakit endokrin lainnya (14). Berat badan yang berlebih akan membuat lebih banyak darah yang dibutuhkan yang menyebabkan tubuh memiliki volume darah berlebih untuk memasok oksigen dan nutrisi ke jaringan tubuh. Volume darah yang beredar melalui pembuluh darah akan meningkat, demikian juga tekanan pada dinding arteri. Obesitas meningkatkan kadar lipid dalam darah (6).

\section{Hubungan indeks massa tubuh (IMT) dengan kejadian hipertensi}

Hasil analisis chi-square didapatkan hasil $p=0,065$ yang menunjukkan tidak terdapat hubungan yang signifikan antara indeks massa tubuh (IMT) dengan kejadian hipertensi (Tabel 4). Hasil penelitian ini sejalan dengan penelitian di Semarang tahun 2014 yang menunjukkan tidak adanya hubungan yang signifikan antara IMT dengan kejadian hipertensi pada wanita menopause di Kelurahan Bojongsalam $(p=0,08)(5)$. Hasil penelitian lain pada tahun 2012 menunjukkan tidak ada hubungan yang signifikan antara IMT dengan tekanan darah pada pasien rawat jalan di Rumah Sakit Tugurejo Semarang (15).

\section{Hubungan usia dengan kejadian hipertensi}

Hasil analisis chi-square menunjukkan terdapat hubungan yang signifikan antara usia dengan kejadian hipertensi $(p=0,008)$, Responden dengan usia $\geq 45$ tahun berisiko 3,37 kali lebih besar untuk mengalami hipertensi ( $O R=3,37,95 \%$ Cl:1,340-8,476) (Tabel 5).

Risiko hipertensi akan meningkat seiring dengan bertambahnya usia seseorang. Ketika usia berada di pertengahan awal, atau sekitar usia 45 tahun, tekanan darah tinggi lebih sering terjadi terutama pada laki-laki. Risiko hipertensi pada wanita lebih sering terjadi setelah wanita mengalami menopause. Wanita menopause berisiko dua kali lebih besar untuk mengalami hipertensi akibat dari menurunnya hormon esterogen yang dapat berfungsi sebagai vasodilator(16).

Hasil penelitian ini sejalan dengan penelitian di Tangerang Banten yang menunjukkan adanya 
hubungan yang signifikan antara peningkatan usia dengan kejadian hipertensi pada pasien rawat jalan dewasa $(p=0,000)$. Responden dengan usia $\geq 45$ tahun berisiko 15,48 kali untuk mengalami hipertensi (OR;15,480, 95\% Cl:5,047- 47,478) (17). Hasil penelitian ini juga sesuai dengan penelitian pada tahun 2006 pada masyarakat Desa Bocor, Kecamatan Bulus Pesantren, Kebumen yang menunjukkan usia merupakan faktor risiko terjadinya hipertensi (18). Penelitian lain tahun 2012 di Cikarang Barat juga menunjukkan adanya hubungan usia dengan kejadian hipertensi pada pasien Puskesmas Telaga Murni, Cikarang (19). Peningkatan usia akan menyebabkan meningkatnya proses-proses degeneratif pada organ-organ tubuh terutama organ sirkulasi yaitu jantung dan pembuluh darah. Pada usia $>45$ tahun akan terjadi peningkatan resistensi (tahanan) pembuluh darah perifer dan aktivitas simpatik (16).

\section{Analisis multivariat}

Beberapa variabel bebas yang masuk analisis mutivariat adalah variabel bebas yang memiliki nilai p kurang dari 0,25. Dalam analisis ini, variabel yang memiliki nilai $p$ kurang dari 0,25 adalah asupan lemak, IMT, dan usia. Berdasarkan Tabel 6, hasil analisis multivariat dengan menggunakan regresi logistik didapatkan variabel yang paling berpengaruh terhadap terjadinya hipertensi pada pasien rawat jalan di RSUD Panembahan Senopati Bantul adalah asupan lemak. Hal ini sejalan dengan penelitian lain tahun 2013 di Kudus yang menunjukkan asupan lemak merupakan faktor yang berhubungan dengan kejadian hipertensi pada pasien Pusling Desa Klumprit UPT Puskesmas Gribig (20).

\section{KESIMPULAN DAN SARAN}

Berdasarkan hasil penelitian dan analisis data yang telah dilakukan selama penelitian di Poli Rawat Jalan RSUD Panembahan Senopati Bantul dapat disimpulkan bahwa terdapat hubungan yang signifikan antara asupan lemak dengan kejadian hipertensi $(p=0,009)$, Responden dengan asupan lemak lebih (> $30 \%$ total kalori sehari) berisiko 3,8 kali lebih besar untuk mengalami hipertensi
(OR:3,839, 95\% Cl:1,357-10,861). Namun demikian, terdapat hubungan positif dan signifikan antara aktivitas fisik yang kurang dengan kejadian hipertensi. Hasil analisis chi-square menunjukkan terdapat hubungan yang signifikan antara usia dengan kejadian hipertensi $(p=0,008)$. Responden dengan usia $\geq 45$ tahun 3,37 kali lebih berisiko untuk mengalami hipertensi $(\mathrm{OR}=3,37,95 \%$ $\mathrm{Cl}: 1,340-8,476)$.

Hasil analisis multivariat dengan menggunakan regresi logistik didapatkan variabel yang paling berpengaruh terhadap terjadinya hipertensi pada pasien rawat jalan di RSUD Panembahan Senopati Bantul adalah asupan lemak dengan nilai $p=0,010$ dan nilai OR (95 Cl):4,246 (1,418 - 12,721).

Bagi ilmu pengetahuan dan institusi pendidikan, hasil penelitian ini diharapkan dapat memberikan informasi tentang hubungan asupan lemak dan aktivitas fisik dengan kejadian hipertensi di RS Panembahan Senopati Bantul. Bagi pemerintah daerah dan dinas kesehatan, hasil penelitian ini diharapkan dapat menjadi usulan perencanaan dan pengembangan program khususnya dalam upaya untuk menurunkan angka kejadian hipertensi.

\section{RUJUKAN}

1. Balitbangkes (Badan Penelitian dan Pengembangan Kesehatan). Riset kesehatan dasar 2013. Jakarta: Badan Penelitian dan Pengembangan Kesehatan RI; 2013.

2. WHO. A global brief on hypertension, silent killer, global public health crisis [Internet]. 2013 [cited 2015 May 25]. Available from: http://ish-world.com/ downloads/pdf/global_brief_hypertension.pdf

3. Rekam medis RS Panembahan Senopati. Laporan diagnosa Unit Rawat Jalan RSUD Panembahan Senopati. Bantul: RSUD Panembahan Senopati Bantul; 2015.

4. Poedjiadi A, Supriyanti F. Dasar-dasar biokimia. Jakarta: UI Press; 2009.

5. Kartini A, Lidiyawati. Hubungan asupan asam lemak jenuh, asam lemak tidak jenuh dan natrium dengan kejadian hipertensi pada wanita menopause di Kelurahan Bojongsalaman. J Nutr Coll. 2014;3(4):612-9. 
6. Zimmermann M. Burgerstein's handbook of nutrition micronutrients in the prevention and therapy of disease. Germany: Thieme; 2001.

7. Kurniawan A. Gizi seimbang untuk mencegah hipertensi [Internet]. 2012 [cited 2015 May 20]. Available from: http://gizi.depkes.go.id/ wp-content/uploads/2012/05/Gizi-SeimbangUtk-Hipertensi.pdf

8. Fathina UA. Hubungan asupan sumber lemak dan indeks massa tubuh (IMT) dengan tekanan darah pada penderita hipertensi. Universitas Diponegoro; 2007.

9. Kapriana M, Sulchan M. Asupan tinggi lemak dan aktivitas olahraga sebagai faktor risiko terjadinya hipertensi obesitik pada remaja awal. Universitas Diponegoro; 2012.

10. Manawan AA, Rattu AJM, Punuh MI. Hubungan antara konsumsi makanan dengan kejadian hipertensi di Desa Tandengan Satu Kecamatan Eris Kabupaten Minahasa. PHARMACONJurnal IIm Farm - UNSRAT. 2016;5(1):340-7.

11. Pescatello L, Franklin B, Fagard R, Farquhar W, Kelley D, Ray C. Exercise and hypertension [Internet]. 2010 [cited 2015 Oct 26]. Available from: http://www.medscape.com/ viewarticle/717056_5

12. Huai $P$, Xun H, Reilly KH, Wang $Y$, Ma W, Xi B. Physical Activity and Risk of Hypertension: A Meta-Analysis of Prospective Cohort Studies. Hypertension [Internet]. 2013Dec 1;62(6):1021-6. Available from: http://hyper.ahajournals.org/cgi/ doi/10.1161/HYPERTENSIONAHA.113.01965

13. Amelia. Hubungan aktifititas fisik dan hipertensi pada lansia di Kecamatan Kasihan Bantul
Yogyakarta 2014. Universitas Alma Ata; 2014.

14. Murray. Biokimia harper. Jakarta: EGC; 2003.

15. Fauziah NY, Bintanah S, Kusuma HS. Hubungan asupan bahan makanan sumber serat, asupan natrium, asupan lemak dan imt dengan tekanan darah pada pasien hipertensi rawat jalan di Rumah Sakit Tugurejo Semarang. J Gizi Unimus. 2015;4(1):8-12.

16. U.S Department of Health and Human Service. Seventh report of the joint national commite on prevention, detection, evaluation, and treatment of high blood pressure. USA: National Institutes of Health National Heart, Lung, and Blood Institute National High Blood Pressure Education Program; 2004.

17. Apriandi F. Hubungan antara peningkatan usia dengan kejadian hipertensi pada pasien yang berobat jalan di Rumah Sakit Bhineka Bhakti Husada Pada Tanggal 19 sampai 30 Juli 2010. UIN Syarif Hidayatullah; 2010.

18. Herke J., Sigarlaki. Karakteristik dan Faktor berhubungan dengan hipertensi di Desa Bocor, Kecamatan Bulus Pesantren, Kabupaten Kebumen, Jawa Tengah, Tahun 2006. MAKARA, Kesehat. 2006;10(2):78-88.

19. Anggara FHD, Prayitno N. Faktor-Faktor Yang Berhubungan Dengan Tekanan Darah Di Puskesmas Telaga Murni, Cikarang Barat Tahun 2012. J IIm Kesehat. 2013;5(1):20-5.

20. Rusnoto DA, Hartinah D. Faktor - faktor yang berhubungan dengan kejadian hipertensi Pada Lansia di Pusling Desa Klumpit UPT Puskesmas Gribig Kabupaten Kudus. J IImu Keperawatan dan Kebidanan. 2013;4(2):18-34. 